\title{
The value of ancient architecture for educational program of masters of architectural space design
}

\author{
Aleksandr Prishchepa ${ }^{1, *}$, Olesya Maidibor ${ }^{1}$ \\ ${ }^{1}$ Don State Technical University, pl. Gagarina, 1, Rostov-on-Don, 344010, Russia
}

\begin{abstract}
The existence of archaeological sites of ancient Greek colonytowns and medieval fortresses gives a real insight into the interaction of all spheres of human activity in ancient times. Ancient Greek Emporium is a vivid example of the architecture, art, archaeology and urban planning synthesis. Archaeological excavations provide an opportunity to study the artefacts of the ancient world belonging to several fields, such as sculpture, decorative arts, fashion design and household. Studying history of archaeology right on the place of excavation of an ancient city masters can imagine the scale of buildings, streets layout and location of business, administrative and residential buildings. It allows students to form professional way of thinking in a short period in order to gather the material and work on the master thesis.
\end{abstract}

\section{Introduction}

Investigating of the problem considered in the article became relevant and necessary while students were preparing for their master's degree in the Architecture Environment Design program. It appeared that forming the image of ancient town in students' minds is a complicated process, which requires not only knowledge in history of architecture, but also knowledge in archeology and history of culture. In our case, ancient emporia located on the Northern coast of the Black Sea and in the Don River delta appeared to be the most effective investigation objects. Many characteristics of such towns are similar, but some of the features define their unicity. During the end of the XX century and till nowadays new archeological materials have been accumulated helping to increase the beliefs about development features of towns of emporia. The Greeks started settling down the Don River and on coasts of the Sea of Azov (Pryazovia) in the VII-VI centuries. The first Greek trading post was found on the Miusskiy peninsula (the territory of present-day Taganrog, Russia). The territory of the Elizabethan ancient city site was settled in the V century. At the beginning of the III century B.C. several colonies founded by bosporan Greeks appeared and the city Tanais arose. All the settlements had very adventitious location. Therefore, the town was developing basing on the place of vessels landing, on the location of the square for trading, of city bathhouses, administrative blocks and household buildings, taking into account wine, butter and fish, which were kept in underground storerooms

"Corresponding author: cafdidpi@mail.ru 
placed under open courtyards. Investigation of town-planning and architectural development of ancient emporia is a theoretical foundation of master's course and of the scientific reconstruction of architectural building groups.

\section{Methods}

Bringing all methods of architecture, design, arts, history and archeology into step will form a new type of creative mentality, which is obligatory for a designer in the contemporary conditions of professional activities.

Taking into account everything written above one can claim that in arts and crafts were high level in Greek emporia including crafting and decorating such leather goods as horse harness, sheath, shoes etc., such clay goods as toys, terracotta, lamps, garnishes, dishes, sculptures, reliefs and figures. In Museum of Regional Studies of Rostov the author of this article as an experiment has replicated the technological process of producing a Maenad terracotta figure by kneading the clay body. He also produced a gypsum relief, an entrance group and a vase. The experiment has showed that all artistic and household products could be manufactured in ordinary living conditions with the use of local materials.

\section{Literature Review}

In her scientific investigations M.A. Karpova marks traditional and specific parameters of ancient settlements. According to Karpova "both the exterior and interior walls used to be luted with clay. The red plaster was used as finishing in Tanais houses". As T.N. Abramova mentions, the first activity in ancient Greek emporia is dated the $3^{\text {rd }}$ century BC. She also points out trade relations in towns of ancient Greece, noticing their "rapid development". $[1,12]$. A technological matching experiment was conducted in ROKM. The experiment goal was to fabricate art and craft items of ancient Greece and small-scale sculptures out of the clay, which had been obtained there. The experiment results are published in archeology magazine "Arkheologiya"[10]. The reports and publications of archaeologists V.G. Zhitnikov [3], V.P. Kopylov [3.4], S.I. Ilyashenko [5] and others are laid at the heart of historical and theoretical basis. Town-planning and architectural aspects are based on the works of S.D. Kryzhitsky, V.P. Tolstikova [6,7], G.V. Esaulova [8].Non-ordinary historical and architectural culture is revealed in works of M.A. Karpova. "As the result of mutual influence of various traditions, territorial peculiarities and house-building specifics a unique culture appeared, the architectural part of which is studied little or not at all" $[2,3]$.

One of specific details mentioned by A.V. Stepanov is order establishment: "Order as a developed constructive-aesthetic system in architecture, as a principle and even as a worldview appeared in ancient Greece" $[9,12]$.

The following years Grand Princes of Russia actively influenced the historical events. T.N. Abramova marks: "In 965 Grand Prince of Kiev Svyatoslav dealt a crushing blow to Khazarkaganat and captured Sarkvel" [1,12]. In particular, that time architectural complexes are being formed, accumulating the wisdom of past centuries. According to V.S. Kukushin "we can see the treasury of wisdom in every detail" [11,12].

Total range of the ancient Greek emporia artifacts directly influences the work of master degree students. A.A. Prishchepa notices: "The teaching of artistic creativity consists in the development of special abilities, the formation of skills and the assimilation of mastery techniques" [12].

\section{Results}


Therefore, the ancient Greek town is a pretty efficient approach to form architectural space for bachelor degree students. It is small in size and its entire infrastructure presence is obvious. It is possible to perform the measurement operations of all environmental zones and to correlate and combine the obtained material to transform their experience in a holistic architectural and spatial object, thereby enabling opportunity to model any other architectural complex.

\section{Discussions}

The main feature of architecture development of the city items listed above is enclosed courtyards. The orientation of structures and streets are systematic, the architectural quarter segments are secluded and closed, the forming partial of the development tends to be a rectangular block with a single-pitched roof. The building entrance groups were disposed inside the courtyards. The roofs of houses located near the city center were made of tiles and the roofs of houses situated behind the rampart were made of bulrush. Some buildings were connected to the watchtowers and fort walls. Greek colonies located on coasts of the lower Don River and on Pryazovia are very similar to architectural traditions of Chersonesus and Panticapaeum. Among their common features is agora and central administrative building presenting propylaea with columns, portico and pediment. Therefore we can understand the wall and load-bearing structures looking on such constructions. A.V. Stepanov notices: "Order as an advanced structural and aesthetic architectural system or as a principle and even ideology appeared in Ancient Greece". In the first century B.C. Vitruvius compared a column with woman's body and told that it represents the unity of architecture and sculpture. A human body commensurate with architecture produced a canonical anthropopathy of Greek order. Apparently, the materials (clay, sandstone, shells) buildings are made of were taken from local pits. Some archeologic excavations prove that Greeks used marble from pits of the Crimean Peninsula. Residential buildings were plastered with reddish material, which shows that they took and used the clay from the city surroundings. The study of ceramic ware showed that a great amount of vases with different stigmas and shadow-graphs of bodies were brought in unlike clay toys and terracotta figures (the last were made of both imported material and local puddle clay with fractions of smashed pottery and other admixtures. It proves that pottery workshops, where ceramic dishes, toys and figures were made, could be found within Greek settlements. Archeologists occasionally find chunks of imported black or red lacquered pottery as well, which indicates particular cultural traditions.

During following centuries the technological methods and natural materials listed above were used not only by Greek colonies but also in Scythian constructions, in developing of Greek cities after destroying by barbarians and in fortresses and medieval residential structures. Analogies can be found in medieval fortresses located in the Rostov region, for example the "Lutic" fortress situated on the coast of the river Mertviy Donets. Then such technologies of ancient Greek emporia construction were used by local tribes, who have adopted a sedentary lifestyle.

In the western outskirt of Tanais the street pattern is structured and to some extent similar to the pattern of the city center. The archeological excavations prove that the city had grid street pattern, as evidenced by two wide streets crossing in right angle. Archeologists say these streets formed in the II century. They also presume that the streets of the first coast terrace go towards the place where the port or harbor was located. In the lower part of the town quarters have remained. Therefore the pattern of the city lies along the coastline like it is in lots of coastal cities. Buildings of the western side of the lower town belong to various types. Classical developments stand next to traditional masonry houses and buildings of clay or sun-dried bricks. Karpova writes: "Inner and outer house 
walls were pugged with clay. Plastering with red covering is known to have been used in house finishing" $[2,12]$.

At the beginning of the IV century A.D. ancient Greek emporia, where Scythians, Sarmatians, Sauromats and many other peoples lived besides Greeks, were destroyed by Huns. In the VI A.D. Uigur nomad tribes called Avars came to the prairies of Don but then they were replaced by Bulgars. One of the Bulgarian tribes is Khazar tribe. Sarkel, the city having been situated on the cost of Don River, was a part of the biggest Khazarkaganate. It also was inhabited by alans. "In 965 Svyatoslav, the Grand prince of Kiev, struck devastating blows to the Khazarkaganate and conquered Sarkel"[1,12].Sarkelwas renamed as White Vezha (Belaya Vezha) and became a big trading town on the lower Don River. Each of the following centuries peoples of Don region changed but building traditions remained the same as in the Greek emporia. White Vezha or White fortress was rebuilt of white air-bricks. The brick kilning technologies were lost. Nowadays it is impossible to execute archeological excavations of White Vezha because the remains of the fortress are flood by the Tsimlyansk Reservoir.

A Cossack kuren (a Cossack national house) is almost square in a plan view, having rectangular dimensional characteristics like houses of Greek colonies. Zone planning of a house had two perpendicularly crossing axis, in the intersection of which there was an oven unlike the fireplace of ancient peoples' houses. The word "kuren" could have come from the Ukrainian word "kurin" which means a hut with a stove but no chimney built of airbricks or clay and puddled with plaster. Such houses (kurens) had no chimney and a smoke leaved a house through the doors and windows. A roof of a kuren hanged over balusters and protected a house from summer heat and sultriness. Ancient houses of the Scythians were round in plan and a roof of such house also hanged down in order to protect walls from the rain and the sun. People call kuren a round house as well. Walls of a kuren were plastered with white or yellow clay borrowed from the local pits. "We find wisdom gathered during ages everywhere". Cossack farm called Nedvigovkakhutor is located almost on the place of ancient hillfort Tanais making archeological excavations rather challenging, but its' planning has remained along the coastline like it was in the ancient town. Besides all town objects of Tanais archeologists found a bathing place, that was bizarre located in the center of the town. Scientists speculate on its direct function. There are several ideas how the bathing place was used. One of them is traditional and another is connected with religious aspect - washing, consecration and voluntary ceremonies. In the towns of the northern Black Sea region the presence of bathing places is a regular thing, but such an odd structured bath in the form of a small pool of masonry and leading down steps has not been found before.

\section{Conclusions}

It's clear from the foregoing that for systemizing knowledge in history of architecture the knowledge pattern should be reconciled with such related fields as archeology and arts. In the master's degree studying process the architectural part of curriculum should be well organized and methodically calibrated. It will directly improve the professional skills of young architects.

The comprehensive view on the historic architectural developing of the city taking into account its' geographical location, river availability, a coastline, a dock, a harbor, a comfortable plan, climatic zones, weather patterns, social groups changing and many other aspects are necessary for a master of architectural environment for his complete knowledge, professional skills spectrum and variety of his design abilities. Master's academic program lasts for 2 years being a period of artistic and creative approaches to the professional activity. 


\section{Acknowledgements}

Special thanks to V.G.Zhitnikov, the head of archeological expedition, the results of which have been laid at the heart of the study on the northern Black Sea region.

\section{References}

1. The people of the Don: ethnographic collections in the collections of museums in the Rostov region (Rostov n.d, 2011)

2. M.A.Karpov, PhD Thesis, 22 (2009)

3. K.K.Marchenko, V.G.Zhitnikov, V.P.Kopylov Elizavetovskoe settlement on the Don (Paleography, Moscow, 2000)

4. V.P.Kopylov,Dokl. scientific. Conf. (2002)

5. S.Ilyashenko, The dissertation, 343 (2007)

6. V.P.Tolstikov,M.B.Muratov, Bulletin of ancient history 1, 176-193 (2013)

7. V.P.Tolstikov, Proceedings of the International Scientific Conference, 18-20 (2013)

8. G.V.Esaulov, The architecture of the South of Russia. From history to the present Publisher Architecture(2016)

9. A.V.Stepanova, The volume-spatial composition (C Architecture, Moscow, 2004)

10. A.A.Prischepa,Antiquity in contemporary art(Arkhyz, Cherkessk, 2012)

11. V.S.Kukushin,The history of architecture of the Lower Don and the Azov Sea(Guingamp, Rostov-on-Don,1996)

12. A.A.Prischepa,Theory and practice of art education in pedagogical high school(Rostov-on-Don, 2003) 